\title{
Character evidence for the monophyly of the Microdesminae, with comments on relationships to Schindleria (Teleostei: Gobioidei: Gobiidae)
}

\author{
ANTHONY C. GILL ${ }^{1} \&$ RANDALL D. MOOI $^{2}$ \\ ${ }^{1}$ International Institute for Species Exploration and School of Life Sciences, PO Box 874501, Arizona State University, Tempe, AZ \\ 85287-4501, USA. E-mail: gill.anthony@gmail.com \\ ${ }^{2}$ The Manitoba Museum, 190 Rupert Ave., Winnipeg, MB R3B 0N2, Canada. E-mail: rmooi@manitobamuseum.ca
}

\begin{abstract}
The composition of the Microdesminae has been inconsistently reported in recent molecular studies. A monophyletic Microdesminae consisting of both Indo-Pacific and New World/Atlantic genera is diagnosed here by the following synapomorphies: maxilla with elongate projection extending anteriorly over ascending processes of premaxilla; palatine medial process absent; single dorsal process on cleithrum; supracleithrum oriented vertically and closely applied to cleithrum; posttemporal with elongate posteroventral process; body slender and elongate, with associated increase in number of vertebrae and median fin rays (total vertebrae 42-66 with 19 or more precaudal vertebrae, total dorsal-fin rays 42-78, anal-fin rays 27-43), slender pelvis with anterior extensions of the pelvic intercleithral cartilage, and decrease in number of pelvic-fin rays (with a spine and 2-4 segmented rays); single dorsal fin; dorsal-fin spines usually 12 or more; predominantly 1:1 relationship between interneural spaces and anterior dorsal-fin pterygiophores; and first (supernumerary) ray on first anal pterygiophore a bilaterally paired, segmented ray. Several of these characters (particularly single dorsal process on cleithrum, posttemporal with elongate posteroventral process) support a possible relationship between microdesmines and Schindleria, as does dorsal gill-arch morphology.
\end{abstract}

Key words: Osteology, Indo-Pacific, Atlantic, New World, systematics, elongation

\section{Introduction}

The familial and subfamilial classification of the acanthomorph fish suborder Gobioidei is in a state of flux, with anywhere between six (Thacker 2009) and nine (Thacker 2000) families recognised in recent classifications. One suprageneric taxon, however, has been relatively stable, consisting of the Indo-Pacific genera Gunnellichthys Bleeker and Paragunnellichthys Dawson, and the New World and east Atlantic genera Microdesmus Günther, Cerdale Jordan \& Gilbert and Clarkichthys Smith. The taxon has been ranked, however, as either the subfamily Microdesminae (e.g., Hoese, 1984, who classified it along with the Ptereleotrinae as the only two subfamilies of the Microdesmidae) or the family Microdesmidae (e.g., by Thacker, 2000, who noted that character evidence for a relationship with the Ptereleotrinae was lacking). Given that there is growing evidence for placement of the group within the Gobiidae (= Gobiidae + Gobionellidae of Thacker, 2009), for the purpose of the current paper we will refer to it as a subfamily (Microdesminae).

Thacker (2000) diagnosed the clade on the basis of seven morphological synapomorphies (character numbers follow Thacker, 2000): "presence of an anterior maxillary projection (7), loss of the inner palatine process that articulates with the lateral ethmoid (16), widely spaced nares (32), a slender pelvis with anterior extensions of the pelvic intercleithral cartilage (41), a single dorsal fin (44), an elevated vertebral number (49; reversed in Cerdale and Clarkichthys), and a body depth of less than $10 \%$ of standard length (52; reversed in Cerdale)." 
In a subsequent molecular study, however, Thacker (2003) placed the three microdesmine genera included in her study (neither Clarkichthys nor Paragunnellichthys were examined) in two different clades: the New World and Atlantic Cerdale and Microdesmus were placed with several other New World taxa, including gobiosomatins and the gobiine Coryphopterus Gill; the Indo-Pacific genus Gunnellichthys was nested within a clade of mostly Indo-Pacific taxa, including Schindleria Giltay, ptereleotrines, and a range of gobiine genera (Eviota Jenkins, Gobiodon Bleeker, Fusigobius Whitley, Amblygobius Bleeker, Valenciennea Bleeker, Callogobius Bleeker, Ctenogobiops Smith, Asterropteryx Rüppell and Amblyeleotris Bleeker). Thacker concluded that the Microdesminae are not monophyletic, dismissing her apparent synapomorphies for the group as follows (p. 366): "Of these characters, two are unique novelties (maxilla projection and pelvis morphology), one is a loss (loss of palatine process), and three are not unique to Microdesmidae (single dorsal fin, body elongation and elevated vertebral number). It is possible that these characters are all functionally associated with the burrowing and feeding (egg predation) habits of these fishes and thus the result of convergence." She did not discuss the seventh synapomorphy (widely spaced nares).

Thacker (2003) did not provide justification for her conclusion that microdesmines are egg predators. Dawson reported that the gut of a specimen of Cerdale floridiana "was completely filled by 97 crustacean eggs containing eyed megalops larvae" (Dawson 1974: 248). In contrast, Myers noted that Gunnellichthys monostigma feeds "primarily on small benthic and pelagic crustaceans" (Myers 1989: 220), and the gut of a specimen of the species examined by us (ASU 18851) contains a small whole shrimp and several unidentified crustacean fragments.

We believe Thacker's (2003) rejection of a monophyletic Microdesminae is premature, particularly given the lack of consistency in recent molecular phylogenies of gobioids. For example, contrasting phylogenies are presented by Akihito et al. (2000), Wang et al. (2001), Thacker (2003), Thacker and Hardman (2005), and Thacker (2009). Indeed, in the latter paper, Thacker retrieved a monophyletic Microdesminae that consisted of both New World/Atlantic and Indo-Pacific taxa. Regardless, the purpose of the present paper is to draw attention to additional characters that support monophyly of the subfamily, as well as to discuss several of Thacker's (2000) characters.

\section{Materials and methods}

Our observations on microdesmines are based on the literature and the following cleared-and-stained specimens (institutional abbreviations follow Eschmeyer, 1998): Cerdale floridana Longley, USNM 396645 (2); Cerdale ionthas Jordan \& Gilbert, GCRL 6563 (1), USNM 396648 (1); Clarkichthys bilineatus (Clark), GCRL V71: 609; Microdesmus dipus Günther, USNM 396646 (1); Microdesmus retropinnis Jordan \& Gilbert, AMNH 49689SW (1), USNM 205071 (2), USNM 396647 (1); Microdesmus longipinnis (Weymouth), GCRL V70: 461; Gunnellichthys monostigma Smith, ASU 18851 (1), MPM 50034 (2); Paragunnellichthys fehlmanni Dawson, USNM 203831 (1, paratype); Paragunnellichthys seychellensis Dawson, GCRL 19583 (1). Our observations on other gobioids include cleared-and-stained specimens of approximately one-half of the 300 or so recognised gobioid genera, including representatives of all currently recognized higher group taxa (e.g., all "putative groups" recognized by Birdsong et al. 1988). This material is not listed here.

\section{Thacker's (2000) synapomorphies}

Some discussion is needed of Thacker's (2000) synapomorphies for the Microdesminae. Firstly, there is a discrepancy between her character summary on page 951, and her phylogeny in figure 7. In that figure, Thacker indicated six synapomorphies for the clade (characters 7, 16, 41, 44, 49 and 52), whereas in the text she noted seven (characters 7, 16, 32, 41, 44, 49 and 52). However, as recognized elsewhere by Thacker (2000), the excluded character (32) is very difficult to defend as a synapomorphy of the subfamily. Thacker 
(p. 947) described the character as anterior naris "far anteriad of posterior naris, adjacent to mouth, nares widely spaced". However, there is considerable variation in anterior nares position among gobioid fishes, with many taxa having them anteriorly positioned over the upper lip (as they are in microdesmines). Although Thacker did not cite the origin of the characters used in her study (many of which had been reported by previous workers), we suspect she may have been erroneously influenced by Gosline's (1955: 169) use of the character "two widely separated nostrils on each side of the head" in diagnosing his Microdesmidae. However, Gosline's use of the character was in the context of differentiation of microdesmines from the "temperate blennioids" (= Zoarcoidei), with which they had been sometimes associated. In contrast to microdesmines (and other gobioids), zoarcoids have a single naris on each side of the head. As noted above, Thacker (2003) did not refer to the character in her subsequent discussion of microdesmine synapomorphies.

Thacker's (2000) character 7 (anterior maxillary projection) appears to date to Gosline (1955: 169), who observed that: "it [his family Microdesmidae] has a peculiar maxillary structure in that the maxillaries send out anterior prolongations which meet or nearly meet each other on the midline in front of the premixillary [sic] pedicels." We concur with Thacker's (2000) treatment of this structure as a synapomorphy of the Microdesminae-even though there is considerable variation in the size of the process-but her illustrations for Cerdale and Microdesmus (fig. 3B and C, respectively) do not do the character justice (although this is partly because the structure is not always clearly visible in lateral views). The character is better illustrated by Dawson (1968: fig. 4; 1974: figs 5, 13, 18 and 23).

Thacker's (2000) characters 41, 44, 49 and 52 are probably manifestations of a single character, elongation. As noted by Gill and Mooi (1993), elongate fishes usually possess a suite of characteristics, which include: relatively high numbers of vertebrae and dorsal and anal-fin rays, reduction of the caudal fin and skeleton, and reduction of the pelvic fins and girdle. For example, Thacker's character 41 (slender pelvis with anterior extensions of the pelvic intercleithral cartilage) is almost identical to the pelvic morphology found in Luciogobius Gill, an unrelated elongate gobiid in Birdsong et al.'s (1988) Astrabe group. Similarly, a reduced number of pelvic-fin rays in microdesmines (character 42 of Thacker 2000) is probably also associated with elongation. Despite a reported consistency index of 1.00, this character did not appear in Thacker's phylogeny due to polymorphic outgroup coding. A reduced number of pelvic-fin rays is known from a few gobiids (e.g. some species of Eviota, Austrolethops Whitley, some species of Hetereleotris Bleeker, some amblyopines, most ptereleotrines); many of these taxa are relatively small-sized or elongate. Although almost all gobioids have two separate (or weakly joined) dorsal fins, elongate taxa often have only a single dorsal (e.g., microdesmines, amblyopines, elongate oxudercines, Gobioides Lacepède, Allomicrodesmus Schultz, and kraemeriines; Schindleria and Luciogobius have single dorsal fins through loss of the spinous dorsal).

The interpretation of homology and definition of character states for meristics such as vertebral number can be troublesome. Inexplicably, Thacker (2000, character 49) defines the outgroup condition as 47 or fewer vertebrae, forcing the microdesmine genera Cerdale and Clarkichthys (42-47 total vertebrae) to share this state with other gobiids (and ignoring the occurrence of 47 in some individuals of Microdesmus). Few gobioids have more than 40 vertebrae: Schindleria has 31-44 (Watson 2000; Watson \& Walker 2004), Luciogobius has 30-42 (Birdsong et al. 1988), Synechogobius Gill has 41-42 (Birdsong et al. 1988), and the microdesmine genera Cerdale has 42-47 (Dawson 1974), Clarkichthys has 45-47 (Dawson 1974), Gunnellichthys has 56-76, Microdesmus has 47-76 (Dawson 1972, 1979), and Paragunnellichthys has 48-54 (Dawson 1967, 1969). Among these taxa, Synechogobius exhibits the common gobioid condition of 16 (or fewer) precaudal vertebrae; Schindleria and Luciogobius have variably 12-24 and 14-20, respectively, whereas microdesmines have a range of 19-39 precaudal vertebrae. Other gobioids that might be considered elongate have more typical or even low precaudal counts: Gobitrichinotus Fowler has 14+16-17 = 30-31 (Birdsong et al. 1988), Gobioides has $10+16-21$ (Birdsong et al. 1988), Platygobiopsis Springer \& Randall has 10+16 = 26 (Okiyama, 2008), Trypauchen Valenciennes has 10+19-24 = 29-34 (Murdy, 2006). Elevated vertebral numbers (40 or more) with high precaudal vertebral counts (19 or more) is clearly derived, and a likely synapomorphy for microdesmines.

Elongation can also be associated with developmental truncation, because (for various reasons) individual structures in elongate taxa are generally much smaller than in related non-elongate taxa. This includes 
reduction of the caudal skeleton and pelvic girdle, as noted above. We note, further, that this phenomenon may extend to additional characters of microdesmines (viz., first anal-fin ray segmented; reduction or absence of certain pectoral-girdle elements).

\section{Additional synapomorphies in support of monophyly of the Microdesminae}

Relatively high number of dorsal-fin spines. As noted by previous authors (e.g., Dawson 1974; Birdsong et al. 1988), microdesmines are distinctive in having 12 (rarely 10 or 11 in two species of Cerdale; Dawson 1974) or more spines in the dorsal fin. Most other gobiids have 7 or 8 spines (one of which is at the front of the second dorsal fin, with the others in the first dorsal fin). However, some basal gobioids and the gobiid genus Synechogobius have as many as 10; the latter has 10 or 11 pterygiophores in the first dorsal fin, but the posteriormost pterygiophore lacks a spine (Birdsong et al. 1988). We interpret the relatively high count as a synapomorphy of the Microdesminae. As noted previously, higher numbers of dorsal-fin elements are often associated with elongation, but the higher number of spines in microdesmines actually counters the usual trend of developmental truncation and reduction in spine number (e.g., Astrabe Jordan \& Snyder, Clariger Jordan \& Snyder, Luciogobius, Allomicrodesmus and kraemeriines among elongate gobioids, and congrogadine pseudochromids, pholidichthyids among other percomorphs all have many rays but few spines). Although Thacker (2000) included a character (47) that acknowledged the relatively high number of dorsalfin spines in microdesmines, she recognised four different states for the character because (p. 948) "in a histogram of species versus range in number of spines, distributions fall into these four groups." This, and the fact that she ran her analysis with the character states unordered, perhaps explains why her analysis did not reveal high number of dorsal-fin spines as a synapomorphy of the Microdesminae.

Single dorsal process on cleithrum. In most gobioids the dorsal tip of the cleithrum is forked (i.e., with two dorsal processes; Fig. 1a; see Springer 1983: figs 14, 16; Rennis \& Hoese 1987: fig. 8; Gill \& Hoese 1993: fig. 8; Winterbottom 1993: fig. 5; Hoese \& Gill 1993: fig. 3); Winterbottom (1993) termed this the "cleithral notch." Baudelot's ligament extends posteriorly from the medial surface of the supracleithrum, through the fork in the cleithrum, then anteriorly to the base of the skull or first vertebra (depending on species). In microdesmines, however, there is only a single dorsal process on the cleithrum (Fig. 1b,c; see also Dawson 1968: fig. 11). Baudelot's ligament extends from the medial surface of the supracleithrum, around the single dorsal process on the cleithrum, then on to the base of the skull. Among gobioids, we are aware of a single dorsal process on the cleithrum only in the genus Schindleria (see Johnson \& Brothers 1993: fig. 12c). However, Schindleria also lacks a supracleithrum and Baudelot's ligament (Johnson \& Brothers 1993). The possibility of a relationship between Schindleria and microdesmines is discussed further below.

Supracleithrum oriented vertically and closely applied to cleithrum. In most gobioids, the supracleithrum extends anterodorsally at an angle of about $45-90^{\circ}$ to the main axis of the cleithrum, to which it is loosely bound (Fig. 1a; see also, for example, Springer 1983: figs 14, 16; Rennis \& Hoese 1987: fig. 8; Gill \& Hoese 1993: fig. 8). In microdesmines, the supracleithrum is more posteriorly positioned, closely applied to the cleithrum, and oriented vertically or more-or-less parallel to the dorsal cleithral process (Fig. 1b,c; see also Dawson 1968: fig. 11).

Posttemporal with elongate posteroventral process. The posttemporal of most gobioids is a v-shaped bone, often with a lateral tab-like process at the angle of the $\mathrm{v}$ (which in many taxa supports a laterosensory canal). The posttemporal articulates with a variously developed condyle on the anterior tip of the supracleithrum (Fig. 1a; see also, for example, Springer 1983: figs 14, 16; Rennis \& Hoese 1987: fig. 8; Gill \& Hoese 1993: fig. 8). Associated with the supracleithrum modification, in microdesmines the posttemporal is instead an obliquely angled, $y$-shaped bone (often with the anteroventral portion of the y mostly unossified and represented by a ligament), with an elongate posteroventral process that loosely overlies the mid-upper or middle part of the supracleithrum. The posteroventral posttemporal process more-or-less occupies the position usually occupied by the supracleithrum in other gobioid taxa (Fig. 1b,c; see also Dawson 1968: fig. 11). We are aware of similar posttemporal morphology among gobioids only in Schindleria, in which the bone is 
blade-like (without an anteroventral arm) and extends posteroventrally from the skull to overlap the upper portion of the cleithrum (Johnson \& Brothers 1993: figs 4e, 12c). The possibility that the condition is homologous in Schindleria and microdesmines is discussed below.
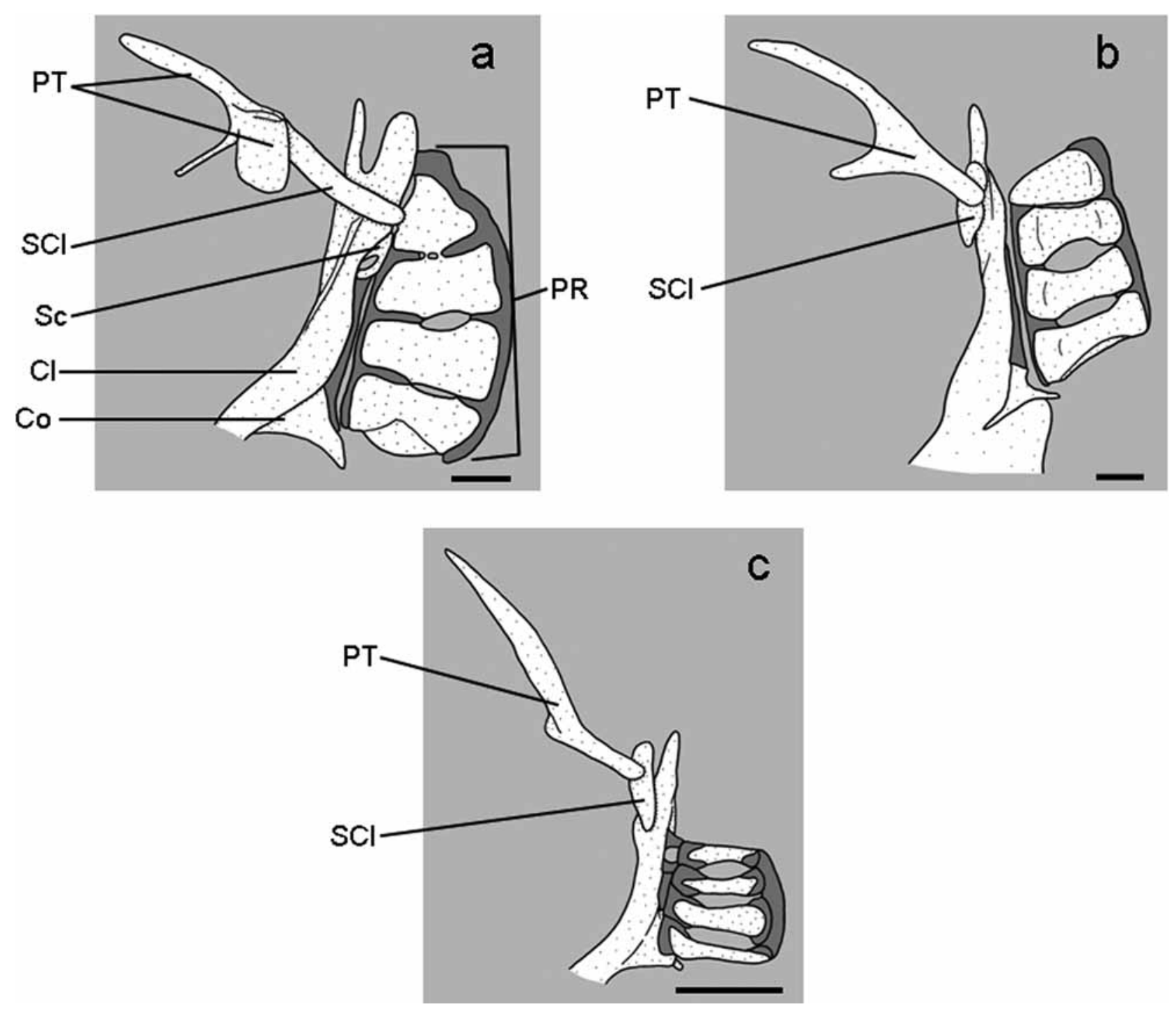

FIGURE 1. Lateral view of dorsal portion of left pectoral girdle of selected gobiids: a) the gobionelline Redigobius macrostoma (Günther), AMS I.31525-001; b) the microdesmine Gunnellichthys monostigma Smith, ASU 18851; c) the microdesmine Microdesmus retropinnis Jordan \& Gilbert, AMNH 49689SW. Abbreviations: Cl - cleithrum; Co coracoid; PR - proximal radials of pectoral fin; PT - posttemporal; Sc - scapula; SCl - supracleithrum. Cartilage shown in grey shading. Baudelot's ligament and unossified (ligamentous) portion of posttemporal not shown. Scale bars represent $0.5 \mathrm{~mm}$.

Predominantly 1:1 relationship between interneural spaces and anterior dorsal-fin pterygiophores. This character was first proposed by Birdsong et al. (1988), who noted (p. 197): "With the exception of the first $2-3$ dorsal pterygiophores in a few species, the spine-bearing pterygiophores each insert into a separate interneural space." However, the character is not unique among gobiids to microdesmines, as it also occurs in Birdsong et al.'s (1988) Astrabe group gobiids, the gobiosomatin genus Evermannichthys Metzelaar and in some species of Kraemeriinae. All of these taxa are relatively elongate, and it is likely that the 1:1 pattern is a consequence of elongation.

First anal-fin ray a bilaterally paired, segmented element. In most gobioids the first (supernumerary) ray on the first anal-fin pterygiophore is a spine. In all microdesmines it is a bilaterally paired, segmented ray. 
A non-spinous first anal ray is relatively rare among gobioids, only being known from the gobiine gobiid genus Trimmatom Winterbottom \& Emery, among various oxudercine and amblyopine genera, variably in the gobiid genera Tasmanogobius Scott and Nesogobius Whitley, in the genus Schindleria, and in the gobionelline gobiid genera Paedogobius Iwata, Hosoya \& Larson, Pandaka Herre, Brachygobius Bleeker, Mistichthys Smith and Gobiopterus Bleeker (Murdy 1989; Hoese 1984, 1991; Johnson \& Brothers 1993; Winterbottom, 1990, 2001; Larson 2001; Hoese \& Larson 2006). As noted by Larson (2001), there is variation in the construction of the fin ray. In Trimmatom and Schindleria the ray is unsegmented, but made up of two fully separate hemitrichs. In gobionellines, the ray is segmented, but may be either separate or united proximally. Regardless of the form, the taxa with a non-spinous first anal-fin ray are often (though not always) either very small or elongate, and it is therefore possible that its presence is due to developmental truncation.
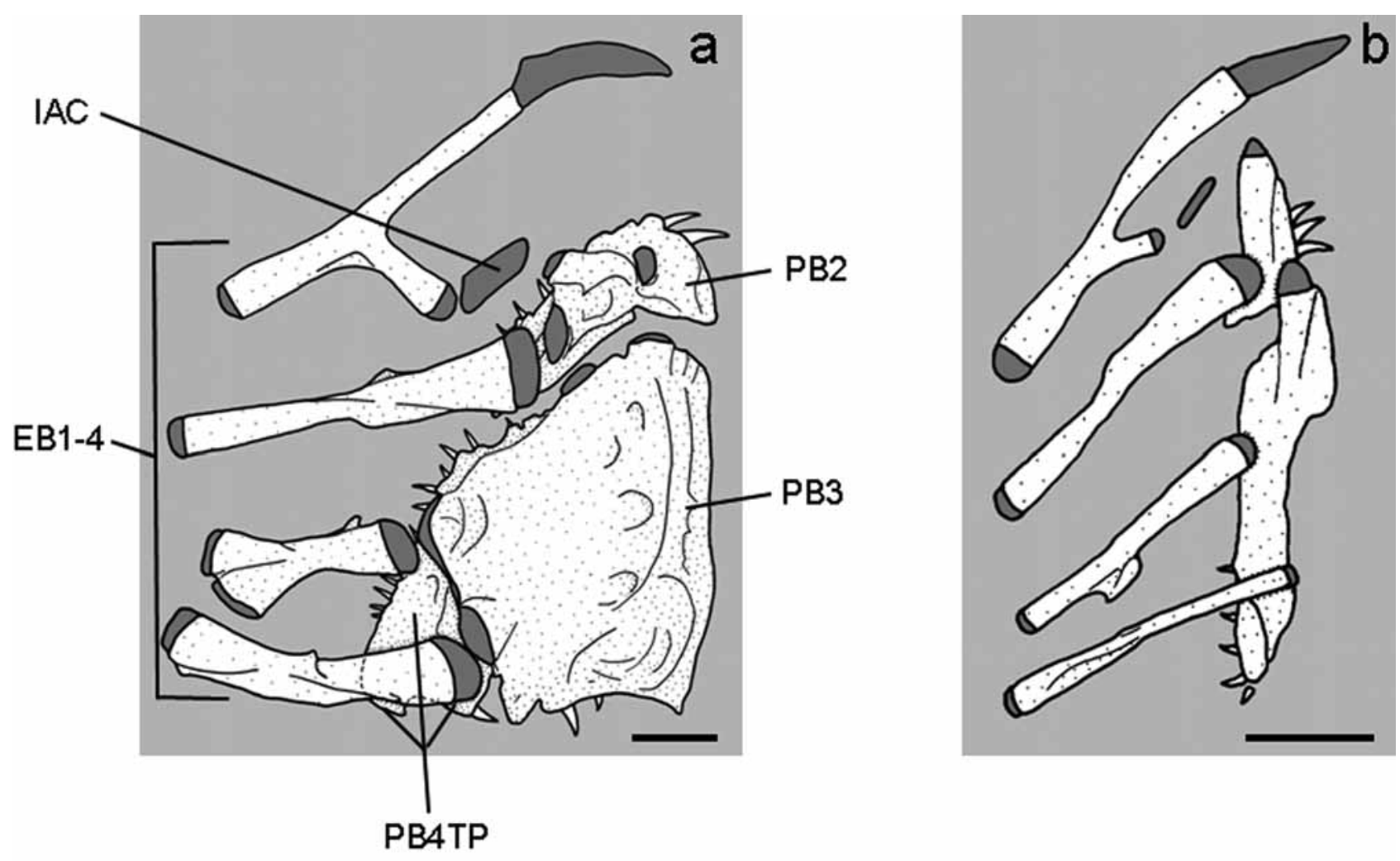

FIGURE 2. Dorsal view of left dorsal gill arches of a) the oxudercine Periophthalmus barbarus (Linnaeus), MPM 45772; b) the microdesmine Gunnellichthys monostigma, ASU 18851. Abbreviations: EB1-4 - epibranchials 1 to 4; IAC - interarcual cartilage; PB2,3 - pharyngobranchials 2, 3; PB4TP - pharyngobranchial 4 tooth plate. Cartilage shown in grey shading. Scale bars represent $0.5 \mathrm{~mm}$.

\section{Cladistic diagnosis of the Microdesminae}

In summary, the Microdesminae is diagnosed among gobioids by the following synapomorphies: maxilla with elongate projection extending anteriorly over ascending process of premaxilla; palatine medial process absent; single dorsal process on cleithrum; supracleithrum oriented vertically and closely applied to cleithrum; posttemporal with elongate posteroventral process; body slender and elongate, with associated increase in number of vertebrae and median fin rays (total vertebrae 42-66 with 19 or more precaudal vertebrae, total dorsal-fin rays 42-78, anal-fin rays 27-43), slender pelvis with anterior extensions of the pelvic intercleithral cartilage, and decrease in number of pelvic-fin rays (with a spine and 2-4 segmented rays); single dorsal fin; dorsal-fin spines usually 12 or more; predominantly 1:1 relationship between interneural spaces and anterior dorsal-fin pterygiophores; and first (supernumerary) ray on first anal pterygiophore a bilaterally paired, segmented ray. 


\section{Potential relationship between Microdesminae and Schindleria}

The phylogenetic position of the highly paedomorphic genus Schindleria had been largely unresolved until Johnson and Brothers (1993) demonstrated that it was nested within the Gobioidei. Although Johnson and Brothers were unable to determine the sister group of the genus, they suggested a possible relationship to microdesmines on the basis of their similar dorsal gill-arch morphology: "The second pharyngobranchial lies fully anterior to the third, so that its posterior tip articulates directly with the anterior tip of the third (also true of Xenisthmus, where PB2 is highly modified as a long, curved, edentate rod) (Johnson \& Brothers 1993: 466). As noted in our introduction, Thacker's (2003) subsequent analysis of mtDNA sequences retrieved a clade consisting of Schindleria and Gunnellichthys, which was nested within a clade consisting of ptereleotrine and various Indo-Pacific gobiine gobiids. The remaining two surveyed microdesmine genera (Cerdale and Microdesmus) were nested within a clade of gobiosomatin and other New World gobiine genera. Thacker noted Johnson and Brother's (1993) pharyngobranchial character, and stated: "The molecular phylogeny supports the morphological character evidence of Johnson and Brothers (1993); further evidence for the placement of Schindleria with Microdesmidae is the observation that the larvae of Gunnellichthys are superficially very similar to Schindleria. Both are elongate, with a continuous dorsal fin, a pointed snout, large eyes and a similar overall morphology" (Thacker 2003: 366). In contrast to Thacker (2003), Thacker's (2009) mtDNA study retrieved a monophyletic Microdesminae, which in turn was sister to a clade consisting of gobiosomatins and Schindleria.

As defined by Johnson and Brothers (1993), the pharyngobranchial character does not withstand scrutiny as a synapomorphy of the Microdesminae and Schindleria. Firstly, our ongoing survey of gobioid dorsal gill arches has revealed various degrees of anterior positioning of pharyngobranchial 2, with the bone well separate from pharyngobranchial 3 among a wide range of gobiids, including certain gobiines (e.g., Valenciennea Bleeker, Istigobius Whitley, Amoya Herre), gobionellines (e.g., Awaous Valenciennes, Gnatholepis Bleeker, Oxyurichthys Bleeker and Gobiopterus Bleeker), and oxudercines (e.g., Parapocryptes Bleeker, Periophthalmus Block \& Schneider; Fig. 2a, see also Murdy 1989: figs 68, 72). More important, however, the two bones overlap in Gunnellichthys (Fig. 2b). Nonetheless, the arrangement in microdesmines is similar to Schindleria in that the pharyngobranchials are elongate, and more-or-less aligned with each other (Fig. 2b). This is in contrast to the other gobiid taxa noted above, where the pharyngobranchials are generally broader and not in alignment: the second pharyngobranchial is usually triangular or crescent-shaped, and usually extends farther laterally, and the fourth pharyngobranchial toothplate is triangular or fan-shaped (Fig. 2a).

Schindleria lacks several of the synapomorphies listed above for microdesmines. There is no elongate projection on the maxilla, there are no dorsal-fin spines, and dorsal-fin pterygiophores are not predominantly in a 1:1 relationship (see Johnson \& Brothers 1993: fig. 5). Although the body is elongate, there are only 3144 vertebrae, 13-22 total dorsal-fin rays and 10-18 anal-fin rays (Watson 2000; Watson \& Walker 2004). However, the absence of dorsal-fin spines and low number of total dorsal-fin rays in Schindleria can be partly attributed to the absence of the first dorsal fin. Unlike in microdesmines, where the two dorsal fins are apparently fused, only the second fin is present in Schindleria. Two other microdesmine synapomorphies (pelvis and pelvic intercleithral cartilage shape; supracleithrum orientation) cannot be logically determined, as these structures are absent in Schindleria.

Schindleria possesses the remaining five microdesmine synapomorphies, although three (absence of medial process on palatine, reduction (absence) of pelvic fin, and first supernumerary ray on first anal pterygiophore a bilaterally paired, segmented ray) may be attributed to small adult size and developmental truncation. The remaining two synapomorphies (single dorsal process on cleithrum; posttemporal with elongate posteroventral process) provide more convincing support for a relationship between Schindleria and microdesmines. Although it is possible that the single dorsal process on the cleithrum is due to developmental truncation, we are not aware of similar morphology in other small-sized gobioids. Moreover, several gobioid larvae and small juveniles examined by us (including representatives of the eleotridid genera Hypseleotris 
Gill, Dormitator Gill and Gobiomorus Lacepède, of the gobiid subfamily Sicydiinae (not identified to genus), and of the gobiid genera Asterropteryx, Gobiopterus Bleeker and Eviota) have dorsally forked cleithra.

\section{Acknowledgements}

V.G. Springer kindly allowed access to specimens in his care. We thank J. Williams and his staff at USNM for loans of specimens. A special thanks to S. Raredon for x-ray images. D.F. Hoese and two anonymous reviewers provided constructive comments. This study was supported by NSF awards DEB-0108244 to RDM and DEB-0541914 to ACG, as well as NSERC Discovery Grant 327844-06 to RDM.

\section{References}

Akihito, Iwata, A., Kobayashi, T., Ikeo, K., Imanishi, T., Ono, H., Umehara, Y., Hamamatsu, C., Sugiyama, K., Ikeda, Y., Sakamoto, K., Fumihito, A., Susumu Ohno, S. \& Gojobori, T. (2000) Evolutionary aspects of gobioid fishes based upon a phylogenetic analysis of mitochondrial cytochrome b genes. Gene, 259, 5-15.

Birdsong, R.S., Murdy, E.O. \& Pezold, F.L. (1988) A study of the vertebral column and median fin osteology in gobioid fishes with comments on gobioid relationships. Bulletin of Marine Science, 42, 174-214.

Dawson, C.E. (1967) Paragunnellichthys seychellensis, a new genus and species of gobiid fish (Microdesmidae) from the western Indian Ocean. Proceedings of the Biological Society of Washington, 80, 73-82.

Dawson, C.E. (1968) Eastern Pacific wormfishes, Microdesmus dipus Günther and Microdesmus dorsipunctatus sp. nov. Copeia, 1968, 512-531.

Dawson, C.E. (1969) Paragunnellichthys fehlmanni, a new gobioid fish (Microdesmidae) from the Indian Ocean. Proceedings of the Biological Society of Washington, 82, 373-380.

Dawson, C.E. (1972) A new eastern Pacific wormfish, Microdesmus knappi (Pisces: Microdesmidae). Proceedings of the Biological Society of Washington, 85, 191-203.

Dawson, C.E. (1974) A review of the Microdesmidae (Pisces: Gobioidei) 1. Cerdale and Clarkichthys with descriptions of three new species. Copeia, 1974, 409-448.

Dawson, C.E. (1979) A new wormfish (Pisces: Microdesmidae) from the eastern tropical Atlantic. Copeia, 1979, 203205.

Eschmeyer, W.N. (1998) Introduction. In W.N. Eschmeyer (Ed.) Catalog of Fishes. Center for Biodiversity Research and Information, California Academy of Science, Special Publication, 1, 7-24.

Gill, A.C. \& Hoese, D.F. (1993) Paraxenisthmus springeri, new genus and species of gobioid fish from the West Pacific, and its phylogenetic position within the Xenisthmidae. Copeia, 1993, 1049-1057.

Gill, A.C. \& Mooi, R.D. (1993) Monophyly of the Grammatidae and of the Notograptidae, with evidence for their phylogenetic positions among perciforms. Bulletin of Marine Science, 52, 327-350.

Gosline, W.A. (1955) The osteology and relationships of certain gobioid fishes, with particular reference to the genera Kraemeria and Microdesmus. Pacific Science, 9, 158-170.

Hoese, D.F. (1984) Gobioidei: relationships. In H.G. Moser, W.J. Richards, D.M. Cohen, M.P. Fahay, A.W. Kendall, Jr., \& S.L. Richardson (Eds.) Ontogeny and systematics of fishes. Special Publication of the American Society of Ichthyologists and Herpetologists, pp. 588-591.

Hoese, D.F. (1991) A revision of the temperate Australian gobiid (Gobioidei) fish genus Tasmanogobius with a comment on the genus Kimberleyeleotris. Memoirs of the Museum of Victoria, 52, 361-376.

Hoese, D.F. \& Gill, A.C. (1993) Phylogenetic relationships of eleotridid fishes (Perciformes: Gobioidei). Bulletin of Marine Science, 52, 415-440.

Hoese, D.F. \& Larson, H.K. (2006) Description of two new species of Nesogobius (Pisces: Gobioidei: Gobiidae) from southern Australia. Memoirs of Museum Victoria, 63, 7-13.

Johnson, G.D. \& Brothers, E.B. (1993) Schindleria, a paedomorphic goby (Teleostei: Gobioidei). Bulletin of Marine Science, 52, 441-471.

Larson, H.K. (2001) A revision of the gobiid fish genus Mugilogobius (Teleostei: Gobioidei), and its systematic placement. Records of the Western Australian Museum, Supplement 62, 1-233.

Murdy, E.O. (1989) A taxonomic revision and cladistic analysis of the oxudercine gobies (Gobiidae: Oxudercinae). Records of the Australian Museum, supplement 11, 1-93.

Murdy, E.O. (2006) A revision of the gobiid fish genus Trypauchen (Gobiidae: Amblyopinae). Zootaxa, 1343, 55-68.

Myers, R.F. (1989) Micronesian Reef Fishes. A Practical Guide to the Identification of the Coral Reef Fishes of the Tropical Central and Western Pacific. Coral Graphics, Barrigada, 298 pp., 144 pls. 
Okiyama, M. (2008) Platygobiopsis tansei, a new species of dorso-ventrally flattened gobiid fish from southern Japan. Bulletin of the National Museum of Natural Sciences, Series A, Supplement 2, 2008, 85-96.

Rennis, D.S. \& Hoese, D.F. (1987) Aioliops, a new genus of ptereleotrine fish (Pisces: Gobioidei) from the tropical IndoPacific with descriptions of four new species. Records of the Australian Museum, 39, 67-84.

Springer, V.G. (1983) Tyson belos, new genus and species of western Pacific fish (Gobiidae, Xenisthminae), with discussions of gobioid osteology and classification. Smithsonian Contributions to Zoology, 390, 1-40.

Thacker, C. (2000) Phylogeny of the wormfishes (Teleostei: Gobioidei: Microdesmidae). Copeia, 2000, 940-957.

Thacker, C.E. (2003) Molecular phylogeny of the gobioid fishes (Teleostei: Perciformes: Gobioidei). Molecular Phylogenetics and Evolution, 26, 354-368.

Thacker, C.E. (2009) Phylogeny of Gobioidei and placement within Acanthomorpha, with a new classification and investigation of diversification and character evolution. Copeia, 2009, 93-104.

Thacker, C.E. \& Hardman, M.A. (2005) Molecular phylogeny of the basal gobioid fishes: Rhyacichthyidae, Odontobutidae, Xenisthmidae, Eleotridae (Teleostei: Perciformes: Gobioidei). Molecular Phylogenetics and Evolution, 37, 858-871.

Wang, H.-Y., Tsai, M.-P., Dean, J. \& Lee, S.-C. (2001) Molecular phylogeny of gobioid fishes (Perciformes: Gobioidei) based on mitochrondrial 12S rRNA sequences. Molecular Phylogenetics and Evolution, 20, 390-408.

Watson, W. (2000) Schindleria (Schindler's fishes). In J.M. Leis \& B.M. Carson-Ewart (Eds) The Larvae of Indo-Pacific Coastal Fishes. (Fauna Malesiana Handbooks 2). E.J. Brill, Leiden, pp. 633-636.

Watson, W. \& Walker, H.J. Jr (2004) The world's smallest vertebrate, Schindleria brevipinguis, a new paedomorphic species in the family Schindleriidae (Perciformes: Gobioidei). Records of the Australian Museum, 56, $139-142$.

Winterbottom, R. (1990) The Trimmatom nanus species complex (Actinopterygii, Gobiidae): phylogeny and progenetic heterochrony. Systematic Zoology, 39, 253-265.

Winterbottom, R. (1993) Search for the gobioid sister group (Actinopterygii: Percomorpha). Bulletin of Marine Science, $52,395-414$.

Winterbottom, R. (2001) Two new gobiid fish species in Trimma and Trimmatom (Teleostei: Gobiidae) from the Indian and Western Pacific Oceans. Aqua, Journal of Ichthyology and Aquatic Biology, 5, 19-24. 